\begin{abstract}
In Timor-Leste, shifting cultivation is still carried out as a form of subsistence agriculture. The objectives of this study are to characterise and reveal the socio-economic importance of shifting agriculture for rural communities in Timor-Leste, highlighting its impacts on the environmental sustainability of ecosystems and the solutions to mitigate their negative impacts. In order to do so, a questionnaire survey was applied to farmers in two Sucos in Bobonaro. Shifting agriculture in Timor-Leste is the basis of subsistence in rural areas, done for home consumption, not implying change in home residence and integrated in family and community life. The negative impacts on the goods and services produced by forests are felt by the surveyed farmers through changes in rainfall and spring water, land loss, climate change, reduction of wild animals, plants and products collected in the forests. Therefore, most farmers expressed no intention to increase the area of shifting cultivation.
\end{abstract}

Keywords: shifting cultivation, forest ecosystems, environmental sustainability, Timor-

Leste, Bobonaro, East Timor, subsistence agriculture, rural communities, sustainable development 


\section{The impact of shifting cultivation in the forestry ecosystems of Timor-Leste}

\section{Maria Jesus}

Escola Portuguesa Ruy Cinatti,

Rua de Balide, Santa Cruz,

Dili, Timor-Leste

Email: fatima_merry@yahoo.com

\section{Pedro Damião de Sousa Henriques}

CEFAGE-UE and Department of Economics,

University of Évora,

Largo dos Colegiais 2,

7004-516 Évora, Portugal

Email: pdamiao@uevora.pt

\section{Pedro Laranjeira}

Ministério dos Negócios Estrangeiros,

Avenida de Portugal,

Dili, Timor-Leste

Email: pedrolaranjeira2002@yahoo.com.br

\section{Vanda Margarida de Jesus dos Santos Narciso}

IAPMEI,

Travessa da Bota, 15,

7000 Évora, Portugal

Email: vandanarciso@gmail.com

\section{Maria Leonor da Silva Carvalho*}

ICAAM - Institute of Mediterranean Agricultural and

Environmental Sciences,

and Department of Economics,

University of Évora,

Largo dos Colegiais 2,

7004-516 Évora, Portugal

Fax: +351-266-740-806

Email: leonor@uevora.pt

${ }^{*}$ Corresponding author 
